\title{
Factors that affect survival in low grade gliomas and the prognostic significance of the $\mathrm{Ki}-67$ proliferation index
}

\section{Düşük dereceli glial tümörlerdesağ|kalımı etkilleyen faktörler ve ki-67 proliferatif indeksinin prognostik öneminin izlenmesi}

\author{
Punar Gökcen ${ }^{1}$, Ender Kurt ${ }^{2}$
}

Department of Gastroenterology, Health Sciences University, Umraniye Training and Research Hospital. Istanbul. Turkey.

${ }^{2}$ Departments of Medical Oncology, Uludağ University, School of Medicine, Bursa, Turkey.

Corresponding author:Pınar Gökçen, MD, Department of Gastroenterology, Health Sciences University, Umraniye Training and Research Hospital,

istanbul, Turkey.

E-mail: pinar-gokcen@ hotmail.com

Received/Accepted:May26, $2020 /$ September18, 2020

Conflict of interest: There is not a conflict of interest.

\section{SUMMARY}

Objective: Low grade gliomas are a heterogeneous group of neoplasms that can progress to malignant gliomas. Various proliferation markers are researched by histopathologists at increasing rates to determine the prognostic behavior of brain tumors. In this study, we aimed to investigate the prognostic significance of the Ki-67 proliferation index in low grade gliomas.

Method: This retrospective study included 38 cases diagnosed with low grade gliomas of WHO grades I and II according to the data retrieved from patient files. Patient characteristics such as age, gender, histology, grade and localization of tumors, treatment options, and recurrence rates were recorded. Immunohistochemical analysis was performed using $\mathrm{Ki}-67$ antibodies, p53, GFAP and others, using paraffin sections.

Results:There were 20 female (\% 52.6) and 18 male (\% 47.4) patients, with a mean age of $40.32 \pm 9.99$ years (range: $23-63$ ). The most common histologic type was oligodendroglioma. The progression-free survival (PFS) time was $35.93 \pm 5.16$ months, and the overall survival (OS) time was $110.98 \pm 9.08$ months. Patients with frontal tumors showed longer survival times compared to those with temporal and parietal tumors $(115.25 \pm 7.42$ versus $47.50 \pm 5.63$ and $33.75 \pm 8.80$ months), respectively (p:0.014). The Ki-67 proliferative index and other clinicopathological characteristics were found to have no effect on PFS and OS.

Conclusions: More comprehensive case series that will use different cutoff values are warranted to understand the effect of the Ki-67 proliferative index on the prognosis and survival in low-grade glial tumours more clearly. Keywords: Glial tumors, Ki-67 antigen, prognostic factors, overall survival, progression-free survival
(D) Pınar Gökçen
(D) Ender Kurt

ORCID IDs of the authors: P.G. 0000-0002-6742-6976 E.K. 0000-0002-5446-1254 
Amaç: Düşük dereceli gliomlar, yüksek dereceli tümöre dönüşme olasılıkları bilinen heterojen bir neoplazi grubudur. Bu tümörlerin prognostik davranışlarını öngörmek için çeşitli proliferasyon belirteçlerinin histopatologlar tarafından kullanımı giderek artmaktadır. Çalışmamızın amac1; Ki-67 proliferatif indeksinin düşük dereceli glial tümörlerdeki prognostik öneminin araştırılmasıdır.

Yöntem: WHO evreleme sistemine göre grade I ve grade II glial tümörlü 38 hastanın tıbbi kayıtları retrospektif olarak değerlendirildi. Hastaların yaş, cinsiyet, tümör histolojisi, grade ve lokalizasyonu, tedavi seçenekleri, rekurrens durumu ve son takipleri kaydedildi. Parafin bloklarda tümörlerin Ki -67 antikor, p53, glial fibriler asidik protein düzeyi immünohistokimyasal boyamalar ile analiz edildi. Ki-67 için sınır değer 100/1000 (\%10) olarak belirlendi.

Bulgular: Hastaların yaş ortalaması $40.32 \pm 9.99$ yıl olup çalışmaya 20 kadın (\% 52.6) ve 18 erkek (\% 47.4) hasta alındı. En s1k görülen histopatolojik tipin oligodendrogliom olduğu görüldü (\%73.7). Hastalıksız sağkalım süresi ortalama 35.93 \pm 5.16 ay ve genel sağkalım süresi ortalama $110.98 \pm 9.08$ ay bulundu. Frontal lokalizasyonlu tümörlerde sağkalım; temporalve paryetal bölgeye göre anlamlı olarak uzun bulundu (115.25 $\pm 7.42 ; 47.50 \pm 5.63$ ve $33.75 \pm 8.80$ ay) (p:0.014). Ki-67 proliferatif indeksinin ve diğer klinikopatolojik parametrelerin hastalıksız sağkalım ve genel sağkalıma etkisi olmadığı görüldü.

Sonuç: Düşük dereceli glial tümörlerde; Ki-67 proliferatif indeksinin prognoz ve yaşam ömrü üzerine etkilerinin daha iyi anlaşılabilmesi için farklı cut-off değerlerinin değerlendirildiği geniş vaka serilerine ihtiyaç vardır.

Anahtarsözcükler: Genel sağkalım, glial tümörler, hastalıksız sağkalım, Ki-67 antijen, prognostik faktörler

\section{INTRODUCTION}

Cancer has been gaining more importance as a health problem in parallel to the increasing lifespan of the world's population. Although malignant primary central nervous system tumours comprise $2 \%$ of all cancers, they are associated with high morbidity and mortality rates. Gliomas constitute $40 \%$ of all tumours and $78 \%$ of all malignant tumours ${ }^{1}$. According to the WHO classification, which considers the presence of atypical cells, mitosis, endothelial proliferation, and necrosis; tumours that do not possess any of these characteristics are classified as grade I and tumours that possess only one of these characteristics, typically atypical cells, are classified as grade II. The most prevalent grade I gliomas are; pilocytic astrocytoma, dysembryoplastic neuroepithelial tumour, pleomorphic xanthoastrocytoma, and ganglioma. On the other hand; astrocytoma, oligodendroglioma, and oligoastrocytoma are involved in the grade II group. Grade I and grade II glial tumours are also referred to as low-grade gliomas (LGG) and account for approximately $30 \%$ of gliomas $^{2}$. Tumours can induce certain clinical symptoms linked to compression, parenchymal infiltration and tissue destruction depending on their localization. Headache, vomiting, and changes in mental state are the most common symptoms ${ }^{3}$. Magnetic resonance imaging (MRI) is the most widely-used imaging method in the determination of the anatomical localizations of tumours due to its high sensitivity. LGGs are noncontrast enhancing lesions that exhibitlow-signal intensity on T1-weighted images and high-signal intensity on T2-weighted and 'fluid-attenuated inversion recovery' (FLAIR) sequences.
Additionally, major metabolites in the tumour tissue can be examined using proton MR spectroscopy. LGGs are expected to demonstrate high choline and low $\mathrm{N}$-acetyl aspartate levels, while the presence of lactate and lipids indicate high proliferative activity ${ }^{4}$.

The treatment modalities for LGGs include chemotherapy, radiotherapy, and surgery; and the treatment decision is made in consideration of the patient's age, functioning, tumour localization, histopathological diagnosis, proliferation markers, gene mutations, and the patient's preferences. The optimal treatment is still controversial ${ }^{5}$. Five-year OS and PFS rates were determined, respectively, as approximately $58-72 \%$ and $37-55 \%$ in randomized studies ${ }^{6}$. It is now known that these tumours demonstrate a pattern of continuous growth and tend to progress to high grades. Therefore, recent years have witnessed an upsurge in studies on the relationship between tumour grade and proliferation markers such as the Ki-67 index and gene mutations such as p53, tumor protein 53 (TP53), phosphatase and tensin homolog (PTEN), cyclin dependent kinase inhibitor 2A (CDKN2A), epidermal growth factor receptor (EGFR), and isocitrate dehydrogenase (IDH).

In this study, we aimed to investigate the prognostic significance of the Ki-67 proliferation index in low grade gliomas which are a heterogeneous group of neoplasms that can progress to malignant gliomas. 


\section{MATERIAL AND METHODS}

\section{Ethics}

This study was planned in accordance with the principles stated in the Helsinki Declaration, patient rights regulations, and ethical guidelines. An approval was granted by Uludag UniversityFaculty of Medicine Medical Research Ethics Committee (Date: 27/03/2012, Approval number: 2012-7/9).

\section{Data Collection}

Data of all patients with intracranial glial tumors who were followed-up bythe Medical Oncology, Radiation Oncology, and Neurosurgery departments of Uludag University, Faculty of Medicine between January 2000-March 2012 were retrospectively evaluated. During the specified period, 209 patients were operated by the Neurosurgery department for a pre-diagnosis of glial tumour. Thirty-eight patients whose pathology reports indicated Grade I and Grade II tumours according to the WHO classification were included in the study. The remaining 171 patients who had Grade III and IV tumours were excluded from the study.

Demographic characteristics, date of glioma diagnosis, tumour histology and localization, type of surgical operation, tumour grade, Ki-67 proliferative index, p53, glial fibrillary acidic protein (GFAP), s-100 and immunohistochemical staining, administered treatment modalities, and recurrences duringfollow-up were retrospectively recorded for all patients. The cut-off value for Ki67 was defined as 100/1000 (\%10). Patients who underwent partial resection and could not be operated were included in the subtotal excision group. PFS was defined as the time fromdiagnosis to recurrence or progression. OS was defined as the time from diagnosis to deathdue to any cause.

\section{Statistical Methods}

Statistical analyses were performed using the widely-used SPSS 13.0 (SPSS for Windows; version 10. 0; SPSS, Inc, Chicago, IL) analysis software. Kaplan Meier analyses were conducted to estimate PFS and OS for all patients. The Log Rank test was used in the evaluation of PFS and OS times in relation to prognostic factors in Kaplan Meier analyses. For continuous variables; mean, standard deviation, minimum and maximum values were provided as descriptive statistics. For categorical variables; frequency and percentages were provided. P-values smaller than 0.05 were considered statistically significant.

\section{RESULTS}

\section{General Data}

Demographic and prognostic characteristics of 38 low-grade glioma cases included in the study are summarised in Table- 1 . There were 20 female (\% 52.6) and 18 male (\% 47.4) patients, with a mean age of $40.32 \pm 9.99$ years (range: $23-63$ ). Of these glial tumours, $16(42.1 \%)$ had a frontal localization and $36(94.7 \%)$ were Grade II tumours. The most frequent tumor histology was oligodendroglioma (73.7\%). On pathological examination, the Ki-67 proliferative index was below the cut-off value in 25 patients $(73.5 \%)$. GFAP positivity was detected in 24 patients $(72.7 \%)$. Of our patients, $26.32 \%$ underwent chemotherapy and $13.2 \%$ radiotherapy. Twenty-five $(65.8 \%)$ patients showed recurrence during follow-up.

\section{Progression-free Survival and Overall Survival Data}

In our series, mean PFS was determined as $35.93 \pm$ 5.16 months (\% 95 confidence interval: 25.8-46.0) and mean OS was determined as $110.98 \pm 9.08$ months (\% 95 confidence interval: 93.2- 128.8).

Being younger or older than 40 years, sex, tumor histopathology and grade, immunohistochemical markers (Ki-67, p53, s-100), treatment modality and recurrence did not have a significant effect on PFS and OS. Since there were only two Grade I tumours and patients who showed positive staining with GFAP did not demonstrate progression or death, the effects of grade and GFAP staining on PFS and OS were not subjected to statistical analyses. The effects of demographic and prognostic parameters investigated in this study on overall survival are shown in Table-2. 
Table-1: Demographic and prognostic characteristics of the cases

\begin{tabular}{|l|c|c|c|}
\hline Variable & $\begin{array}{c}\text { Number of } \\
\text { Patients n (\%) }\end{array}$ & Variable & $\begin{array}{c}\text { Number of } \\
\text { Patients n (\%) }\end{array}$ \\
\hline Age & & Ki-67 & \\
$\leq 40$ & $20(52.6)$ & $\geq 100 / 1000$ & $9(26.5)$ \\
$>40$ & $18(47.4)$ & $<100 / 1000$ & $25(73.5)$ \\
\hline Sex & & P53 & \\
Female & $20(52.6)$ & Positive & $10(55.6)$ \\
Male & $18(47.4)$ & Negative & $8(44.4)$ \\
\hline Histology & & GFAP & \\
Oligodendroglioma & $28(73.7)$ & Positive & $24(72.7)$ \\
Astrocytoma & $4(10.5)$ & Negative & $9(27.3)$ \\
\cline { 4 - 4 } Other & $6(15.8)$ & Excision & \\
Grade & & Total & $16(42.1)$ \\
Grade1 & $2(5.3)$ & Subtotal & $22(57.9)$ \\
Grade2 & $36(94.7)$ & Chemotherapy & \\
Localization & & Yes & $10(26.3)$ \\
Frontal & $16(42.1)$ & No & $28(73.7)$ \\
Temporal & $4(10.5)$ & Radiotherapy & \\
Parietal & $6(15.8)$ & Yes & $5(13.2)$ \\
Other & $12(31.6)$ & No & $33(86.8)$ \\
\hline
\end{tabular}

Patients with a Ki-67 proliferative index above the cut-off value and those with an index below the cutoff value showed PFS times of $47.11 \pm 8.56$ months (95\% confidence interval: 30.3-63.9) and $69.5 \pm$ 6.1 months (95\% confidence interval: 57.5-81.4), respectively, with no statistically significant difference $(p=0.382)$. PFS times for frontal, temporal, and parietal lobe localizations were determined, respectively, as $56.8 \pm 3.9$ months (95\% confidence interval: 49.0- 64.6 months), 28.3 \pm 7.0 months $(95 \%$ confidence interval: 14.4 42.2 ); and $30.1 \pm 10.1$ months (95\% confidence interval: $10.2-50.1)$, with no statistically significant differences $(\mathrm{p}=0.053)$. The PFS curve is provided in Figure-1, independently of prognostic factors.
The effects of the Ki-67 proliferative index on OS were examined; patients with values higher than the cut-off had an OS time of $83.0 \pm 16.4$ months and those with values lower than the cut-off had an OS time of $115.6 \pm 11.1$ months, with no statistically significant difference between the two groups ( $\mathrm{p}=0.300$ ). OS was determined as $115.2 \pm$ 7.4 months in patients with frontal localizations, as $33.7 \pm 8.8$ months in patients with parietal localizations, and as $47.5 \pm 5.6$ months in patients with temporal localizations. This finding was statistically significant $(\mathbf{p}=\mathbf{0 . 0 1 4})$. The OS curve showed a high mortality rate until the 40th month with stabilization thereafter, independently of prognostic factors (Figure-2). 
Table-2: Effects of prognostic parameters on overall survival

\begin{tabular}{|c|c|c|c|}
\hline Variable & $\begin{array}{c}\text { Overall Survival } \\
\text { (months) } \\
\text { Mean } \pm \text { SD } \\
\end{array}$ & $\begin{array}{l}\text { (95\% confidence } \\
\text { interval) }\end{array}$ & $\mathbf{p}$ \\
\hline \multicolumn{4}{|l|}{$\overline{\text { Age }}$} \\
\hline$\leq 40$ & $95.61 \pm 9.96$ & $76.1-115.1$ & \\
\hline$>40$ & $109.73 \pm 13.23$ & $83.8-135.7$ & p: 0.757 \\
\hline \multicolumn{4}{|l|}{ Sex } \\
\hline Female & $114.52 \pm 11.39$ & $92.2-136.9$ & \\
\hline Male & $91.89 \pm 11.34$ & $69.7-114.1$ & p: 0.836 \\
\hline \multicolumn{4}{|l|}{ Histology } \\
\hline Oligodendroglioma & $114.39 \pm 10.36$ & 94. 1- 134.7 & \\
\hline Astrocytoma & $49.50 \pm 21.26$ & $7.8-91.2$ & \\
\hline Other & $100.00 \pm 16.10$ & $68.5-131.6$ & p: 0.242 \\
\hline \multicolumn{4}{|l|}{ Localization } \\
\hline Frontal & $115.25 \pm 7.42$ & $100.7-129.9$ & \\
\hline Temporal & $47.50 \pm 5.63$ & $36.5-58.5$ & \\
\hline Parietal & $33.75 \pm 8.80$ & $16.5-51.0$ & p: 0.014 \\
\hline \multicolumn{4}{|l|}{$\overline{\text { Excision }}$} \\
\hline Total & $101.140 \pm 16.53$ & $68.7-133.6$ & \\
\hline Subtotal & $57.42 \pm 4.83$ & 48. $0-66.9$ & p:0.602 \\
\hline \multicolumn{4}{|l|}{ Ki-67 } \\
\hline$\geq 100 / 1000$ & $83.00 \pm 16.45$ & $50.8-115.2$ & \\
\hline$<100 / 1000$ & $115.63 \pm 11.16$ & $93.8-137.5$ & p:0.300 \\
\hline \multicolumn{4}{|l|}{$\mathbf{P 5 3}$} \\
\hline Positive & $50.06 \pm 9.69$ & $31.1-69.1$ & \\
\hline Negative & $59.71 \pm 4.89$ & $50.1-69.3$ & p:0.333 \\
\hline \multicolumn{4}{|l|}{ S- $100(+)$} \\
\hline Positive & $61.89 \pm 4.82$ & $52.4-71.3$ & \\
\hline Negative & $105.89 \pm 11.42$ & $83.5-128.3$ & p:0.930 \\
\hline \multicolumn{4}{|l|}{ Chemotherapy } \\
\hline Yes & $57.18 \pm 6.03$ & $45.4-69.0$ & \\
\hline No & $110.80 \pm 10.49$ & $90.2-131.4$ & p:0.809 \\
\hline \multicolumn{4}{|l|}{ Radiotherapy } \\
\hline Yes & $39.50 \pm 1.06$ & 37.4- 41.6 & \\
\hline No & $111.76 \pm 9.42$ & $93.3-130.2$ & p:0.897 \\
\hline
\end{tabular}


Survival probability

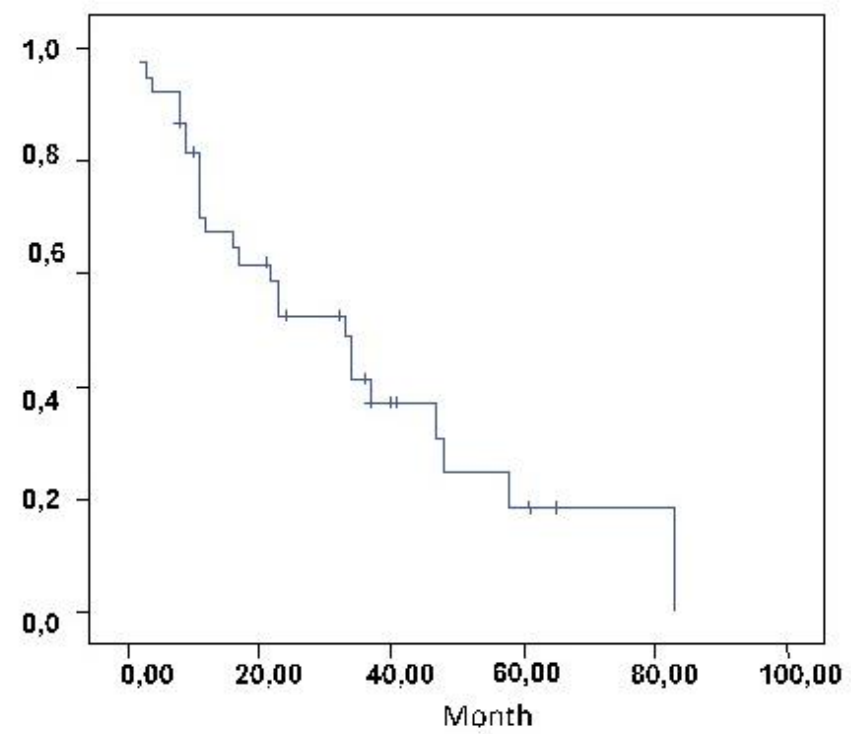

Figure1: Kaplan Meier survival curve for progression-free survival

Survival probability

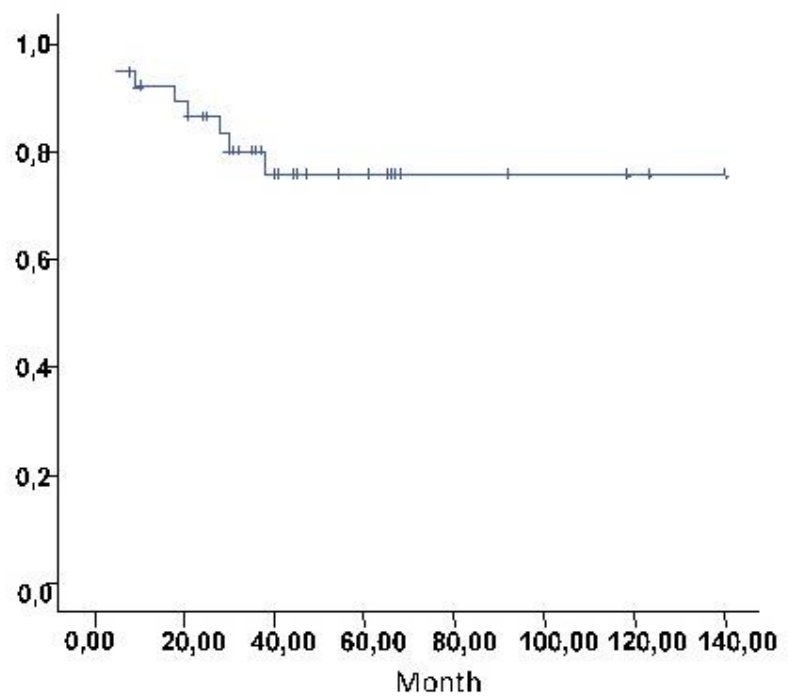

Figure2: Kaplan Meier survival curve for overall survival

\section{DISCUSSION}

Tumours of the central nervous system are uncommon but have a high mortality rate. Although they comprise $1.4 \%$ of all new cancer diagnoses, they account for $2.6 \%$ of all cancerrelated mortality ${ }^{7}$. Today, it is an accepted view that LGGs can undergo malignant transformations even though they are associated with longer survival times compared with other brain tumours. Five-year survival from diagnosis ranged between $58-72 \%$ in three comprehensive studies (EORTC22844, EORTC22845, NCCTG) that included 836 patients. In our series, the mean PFS was determined as $35.9 \pm 5.16$ months $(95 \%$ 
confidence interval: $25.8-46.0)$ and the mean OS as $110.98 \pm 9.08$ months $(95 \%$ confidence interval: 93.1-128.7). Survival times of patients with brain tumours are influenced by various factors. These factors can be listed as patient age, sex, tumour type, tumour grade and localization, success of the surgical operation, and the treatment options administered post-operatively. In our study; age, sex, tumour histopathology and grade, immunohistochemical markers (Ki-67, p53, s100), and treatment modality did not have a significant effect on PFS and OS.

It is known that an advanced patient age is negatively correlated with survival and that younger patients show a better prognosis and longer survival times. The histological structure of the tumour is influenced by advanced age and reduced body resistance. In older patients with high-grade astrocytoma, the histological structure of the tumour was shown to be influenced particularly by the increased vascular proliferation and this was shown to be linked to shorter survival times. Increase in the aggressive behaviour of the tumour due to the decrease in cellular immunity and reduced tolerance to treatment at advanced ages are also thought to contribute to this situation ${ }^{11}$. The consideration of mean survival times with respect to the age distribution of the patients included in our study showed that OS was longer at younger ages; however, this difference was not statistically significant $(\mathrm{p}=0.757)$. This can be connected to the relatively low number of patients included in our study or the better toleration of the new generation temozolomide-based chemotherapy and new techniques in radiation therapy by older patients. The effects of gender on the prognosis and survival times associated with brain tumours are controversial. In the present study, female patients showed longer survival times, albeit without a statistically significant difference between the sexes $(p=0.836)$. The general view is that female patients have a better prognosis than male patients. This finding can be linked to the higher prevalence of meningiomas in female patients ${ }^{1}$. There are also certain series that have explained the worse prognosis in male patients by the greater frequency of multiple tumours.

The histological classifications and grades of brain tumours are important prognostic factors that influence survival times. Oligodendrogliomas are associated with longer survival times than astrocytomas and mixed gliomas ${ }^{3}$. Studies that have investigated the effect of tumour grade on survival times in LGGs have produced conflicting results. Although these tumours generally appear to exhibit slow progression and longer survival times, studies on how survival times are affected when these tumours are graded with respect to their histological types are limited. Overall survival times associated with the histological types of the tumours included in our study were determined as follows; $49.50 \pm 21.26$ months for astrocytomas and $114.39 \pm 10.36$ months for oligodendrogliomas. This result was nonsignificant, most likely because patients were not distributed homogenously. There were only 2 patients with Grade I tumours and the effects of the grades of LGGs on PFS and OS could not be statistically inspected. However, OS times were numerically longer in oligodendrogliomas, corroborating the literature data suggesting that oligodendrogliomas respond better to treatment and demonstrate a better prognosis ${ }^{3}$. Tumour localization is another factor that influences survival times. Tumours localized near vital centres of the brain are known to be linked to shorter survival times. This can be explained by the limited surgical treatment options that the patient can undergo and that only a palliative approach can be administered. A larger tumour size was also considered an important prognostic factor due to the neurological damage and metabolic disorders caused by the compression effect. In the present study, the OS was determined as $115.25 \pm 7.42$ months in patients with frontal localizations, as $47.50 \pm 5.63$ months in patients with temporal localizations, and as $33.75 \pm 8.80$ months in patients with parietal localizations; and these differences were statistically significant $(\mathrm{p}=0.014)$. This can be connected to the early detection of frontal lesions due to manifesting clinical symptoms at earlier stages and the safer application of extended resection in this localization. There are publications in the literature that support our study and report shorter survival times for temporal localizations, while some also argue that survival is influenced more by a multifocal localization than by the localization of the tumour ${ }^{13,14}$. In our series, there was a statistically significant difference despite the low number of patients with multifocal tumours, reinforcing the notion that tumours with temporal and parietal localizations have a less favourable prognosis.

The treatment of LGGs is still controversial. In the past, a "wait-and-see" approach would be adopted when a healthy young adult was diagnosed with LGG; whereas today, early treatment approaches garner more attention as the natural progression of these tumours is understood more clearly. In studies on glioma kinetics, glioma development was found to continue in the premalignant phase that preceded anaplastic transformation. This 
explains the potential of LGGs to transform into malignant gliomas ${ }^{15}$. LGGs are infiltrative tumours that can have undefinedmargins, the microinvasion of which can extend beyond the radiological margins. Today, the standard approach is to perform a total resection if it is technically possible. Patients who undergo radical or subtotal resection are known to achieve longer survival times than those who only undergo a biopsy ${ }^{13}$. In conclusion, the surgical treatment decision is made in consideration of tumour localization and spread in brain tumours. In the present study, the 16 patients who could undergo total excision showed an overall survival of $101.140 \pm 16.53$ months, and the 22 patients who underwent subtotal excision showed an overall survival of $57.42 \pm 4.83$ (47. 9666. 89) months. Although this difference was not statistically significant, it still reveals the superior benefit of complete excision. Determining the standalone effect of radiotherapy (RT) on survival times in LGGs is challenging as tumour control can usually be achieved through total resection. The most important issues in the planning of RT are its timing, the determination of the effective dose, and establishing a benefit-harm balance. Stereotactic radiosurgery was developed to maintain control over small regions in recurrent malignant gliomas and there is no data on its effectiveness and safety in the treatment of LGGs. RT is usually recommended forpatients who have a high mitotic index or show recurrence in their follow-up imaging examinations. Postoperative RT was shown to increase five-year survival rates and delay tumour recurrence in patients who could only undergo subtotal excision due to the localization of the tumour ${ }^{16}$. It is unclear if the main factor that influences survival in LGGs treated with postoperative RT is tumour grade or RT ${ }^{17}$. Moreover, in most LGGs, particularly in young patients, RT can be delayed until progression or after chemotherapy, as done in oligodendrogliomas, due to its potential to create permanent brain damage. The fact that only 5 patients in our series received RT supports this approach, however, renders it impossible to statistically analyse the effectiveness of RT. Chemotherapy is considered for patients who show progression after surgery and RT and patients at high risk after surgery. Genetic tests must be taken into account in chemotherapy decision-making. Glial tumours accompanied by the loss of chromosomes (1p) and (1p19q)were shown to be chemosensitive and these cases showed longer PFS and OS times ${ }^{18}$. The general view is that larger and higher-grade tumours respond better to chemotherapy. Accordingly, our study also determined longer OS times in patients who were more appropriate for surgery due to less aggressive tumour behaviour and did not undergo chemotherapy. Chemotherapy options include; the PCV regimen that consists of procarbazine, lomustine, and vincristine, and temozolomide therapy. Both options are associated with similar response times over 10-24 months of follow-up but temozolomide was found to be tolerated better ${ }^{19}$. Signal transduction inhibitors, angiogenesis inhibitors, monoclonal antibodies, immunotoxins, and gene transfer therapies are also being investigated as novel agents.

The most popular proliferation-related nuclear markers in the prediction of the progression of glial tumours are the Ki-67 antibody (MIB 1 index) and p53. Ki-67, which is a monoclonal antibody that was first produced in mice immunized with a nuclear fraction derived from a Hodgkin lymphoma cell culture in 1983; is a non-histone protein raised against the Ki-67 epitope, an antigen found in the non-histone proteins of cells in the G1, $\mathrm{S}, \mathrm{G} 2$ and $\mathrm{M}$ phases of the cycle. Ki-67 provides prognostic data regardless of the histopathological stage and localization of the tumour ${ }^{20}$. Diffuse Grade II astrocytomas have a Ki-67 index of approximately $1-2 \%$, while this rate is between 15 $40 \%$ in Grade IV astrocytomas ${ }^{21}$. In a pathological evaluation of 167 glioblastoma multiforme cases, $62.8 \%$ of the patients with high Ki-67 expression rates (cut-off $25 \%$ ) demonstrated significantly shorter PFS and OS times ${ }^{22}$. Another study conducted on 50 patients with glial tumours of various histology and grades, the Ki-67 index showed a strong correlation with grade, while p53 showed a weak correlation ${ }^{23}$. In the present study, the Ki-67 index did not show a statistically significant correlation with survival. This was thought to be linked to the fact that only two of the patients with Ki-67 levels above the cut-off value could undergo resection and that four patients with levels below the cut-off value discontinued followup. It was reasoned that such numbers of patients could influence significance in the present study, which included 38 patients in total. Our study supports the limited literature data on such cases; however, there is still no consensus on the effect of the Ki-67 index on survival in LGGs. The studies that have investigatedthe effects of the Ki-67 index on the prognosis in glial tumours mostly included high-grade tumours as well. ${ }^{23,24}$ In this sense, large patient series that will only include low-grade tumours are needed. The Murin Double Minutes 2 (MDM 2) gene is located in the (12q13-14) region of the chromosome and codes for the MDM 2 protein. This protein binds to $\mathrm{p} 53$, inhibiting its apoptotic effect, and initiates glioma oncogenesis. The inhibition of the synergistic action of p53 with 
inhibitor proteins such as (p16) and (p21) is thought to facilitate conversion to more malignant forms ${ }^{25}$. Immunohistochemical studies determined pMDM 2 overexpression at rates of $52 \%$ in primary glioblastomas and $11 \%$ in secondary glioblastomas ${ }^{26}$. Further, p53 overexpression was also shown to be related to the presence of an intact (1p) chromosome in oligodendroglial tumours ${ }^{27}$. In the present study, p53 did not show a significant correlation with survival times. This finding supports publications that have argued for the absence of a relationship between p53 overexpression and survival. Studies that showed a negative correlation between p53 overexpression and survival present variability in the adopted cutoff values and the tumour grades of the included patients ${ }^{25}$. Glial fibrillary acidic protein (GFAP) is typically found in connection with fibrillary astrocytomas in the literature. There is evidence suggesting that GFAP is correlated with TNF-alpha in astrocytomas and plays a role in the pathogenesis of tumours ${ }^{28}$. In our study, the effects of GFAP on survival could not be statistically analyzed as GFAP-negative patients did not show progression or mortality. This could be related to the fact that the astrocytoma histology was found in only a few patients. Lastly, current prognostic studies on gliomas continue to focus on immunohistochemical markerssuch as the loss of chromosomes (1p19) and (9p21); TP53, isocitrate dehydrogenase enzyme (IDH), PTEN, CDKN2A, and EGFR mutation analyses; mitosin (p330d/CENP-), nuclear DNA topoisomerase II $\alpha$ (TII $\alpha$ ), and survivin.

\section{CONCLUSION}

Low-grade glial tumours have a tendency to show steady growth and progress to higher grades and this has garnered interest in proliferation markers that can predict the prognosis. In the evaluation of factors that could affect progression-free survival and overall survival; age groups, the $\mathrm{Ki}-67$ proliferative index and other histochemical measurements, and treatment modalities were found to have no statistically significant effect. However; albeit non-significant, female sex, oligodendroglioma histology, and total excision showed numerical differences as high as 2.5- to 3fold, suggesting that these characteristics could have an effect on survival. Tumours with frontal localizations, which are associated with high resectability, were linked to longer OS times. Studies with large case series that could verify our data are needed to evaluate the current conventional prognostic markers and novel markers.
Acknowledgements: We would like to thank the Neurosurgery, Radiation Oncology, and Pathology Departments of Uludag University, Faculty of Medicine for their contribution to this study.

\section{REFERENCES}

1. Buckner JC, Brown PD, O'Neill BP, et al. Central nervous system tumors. Mayo Clin Proc 2007; 82: 1271-86

2. Central Brain Tumor Registry of the United States. Statistical Report: Primary Brain and Central Nervous System Tumors Diagnosed in the United States in 2004-2008 (March 23, 2012 Revision) Hinsdale, IL: CBTRUS; 2012.

3. Duffau L, Capelle L. Preferential brain locations of low-grade gliomas. Cancer 2004; 100: 2622-6.

4. Henson JW, Gaviani P, Gonzalez RG. MRI in treatment of adult gliomas. Lancet Oncol 2005; 6: 167-75.

5. Schiff D, Brown PD, Giannini C. Outcome in adult low-grade glioma: the impact of prognostic factors and treatment. Neurology 2007; 69: 1366-73.

6. Claus EB, Black PM. Survival rates and patterns of care for patients diagnosed with supratentorial low-grade gliomas: data from the SEER program, 1973-2001. Cancer 2006; 106: 1358-63.

7. Howlader N, Noone AM, Krapcho M, et al. SEER Cancer Statistics Review, 1975- 2012. http://seer.cancer.gov/csr/1975_2012/.

8. Hoang-Xuan K, Capelle L, Kujas M et al. Temozolomide as initial treatment for adults with low-grade oligodendrogliomas or oligoastrocytomas and correlation with chromosome 1p deletions. J Clin Oncol 2004; 22: 3133-8.

9. Quinn JA, Reardon DA, Friedman AH, et al. Phase II trial of temozolomide in patients with progressive low-grade glioma. J Clin Oncol 2003; 21: 646-51.

10. Murphy PS Viviers L, Abson C, et al. Monitoring temozolomide treatment of lowgrade glioma with proton magnetic resonance spectroscopy. Br J Cancer 2004; 90: 781-6.

11. Hirano H, Asakura T, Yokoyama S, et al. The prognostic factors in astrocytic tumors: analysis by the Kaplan-Meier method and the Weibull log-linear model. No Shinkei Geka 1996; 24(9): 809-15.

12. Gorlia T, Stupp R, Eisenhauer EA, et al. European Organisation for Research and Treatment of Cancer (EORTC) Brain And Radiotherapy Groups, National Cancer Institute of Canada (NCIC) Clinical Trials 
Clinical prognostic factors affecting survival in patients with newly diagnosed Glioblastoma Multiforme (GBM) Group40th ASCO Annual Meeting. New Orleans, LA. June 5- 8, 2004. Abstract No. 9599 (Clinical Study).

13. Phi JH, Chung CK. Brain tumors in the mesial temporal lobe: long-term oncological outcome. Neurosurg Focus 2009; 27(2): E5.

14. Reavey-Cantwell JF, Haroun RI, Zahurak M, et al. The prognostic value of tumor markers in patients wit glioblastoma multiforme: analysis of 32 patients and review of the literature. Neurooncol 2001; 55(3): 195-204.

15. Mandonnet E, Delattre JY, Tanguy ML, et al. Continuous growth of mean tumor diameter in a subset of grade II gliomas. Ann Neurol 2003; 53: 524-8.

16. Packer RJ, Sutton LN, Rorke LB, et al. Oligodendroglioma of Posterior fossa in Childhood. Cancer 1985; 56: 195-9.

17. Cancer Facts and figures 2002, American Cancer Society, Surveillance Research, Atlanta, 2002.

18. Cairncross JG, Ueki K, Zlatescu MC, et al. Specific genetic predictors of chemotherapeutic responce and survival in patients with anaplastic oligodendrogliomas $\mathbf{J}$ Natl Cancer Inst 1998; 90: 1473-9.

19. Van den BMJ, Taphoorn MJ, Brandes AA, et al. Phase II study of first-line chemotherapy with temozolomide in recurrent oligodendroglial tumors: the European Organization for Research and Treatment of Cancer Brain Tumor Group Study 26971. J Clin Oncol 2003; 21: 2525-8.

20. Kros JM, Hop WC, Godschalk JJ et al. Prognostic value of the proliferation-related antigen Ki-67 in oligodendrogliomas. Cancer 1996; 78: 1107-13.

21. Burger PC, Scheithauer B, Vogel FS. Surgical Pathology of the Nervous System and Its Converings, Fourth Edition. New York: Churchill Livingstone 2002.

22. Jin Q, Zhang W, Qiu XG, et al. Gene expression profiling reveals Ki-67 associated proliferation signature in human glioblastoma. Chin Med J 2011; 124: 2584-8.

23. Arshad H, Ahmad Z, Hasan SH. Gliomas: Correlation of Histologic Grade, Ki67 and p53 Expression with Patient Survival. Asian Pacific J Cancer Prev 2010; 11: 1637- 40.

24. Kayaselçuk F, Zorludemir S, Gümürdühü D, Zeren H, Erman T. PCNA and Ki-67 in central nervous system tumors: correlation with the histological type and grade. Journal of Neuro-Oncology 2002; 57: 115-21.

25. Kato H, Kato S, Kumabe T, et al. Functional evaluation of p53 and PTEN gene mutations in gliomas. Clin Cancer Res 2000; 6(10): 3937-43.

26. Biernat W, Kleihues P, Yonekawa Y, et al. Amplification and overexpression of MDM2 in primary (de novo) glioblastomas. J Neuropathol Exp Neurol 1997; 56: 180- 185.

27. Hirose T, Ishizawa K, Shimada S. Utility of in situ demonstration of $1 \mathrm{p}$ loss and p53 overexpression pathologic diagnosis of oligodendroglial tumors. Neuropathology 2010; 30(6): 586- 96.

28. Niranjan R, Kamat PK, Nath C, Shukla R. Evaluation of guggulipid and nimesulide on production of inflammatory mediators and GFAP expression in LPS stimulated rat astrocytoma, cell line (C6). Journal of Ethnopharmacology 2010; 127(3): 625-30. 